\title{
PELATIHAN PEMBUATAN DENDENG BAGI KELOMPOK PEMBURU DAN PENJUAL DAGING RUSA DI KAMPUNG UKOPTI, KAWASAN PENYANGGA CAGAR ALAM PEGUNUNGAN ARFAK PAPUA BARAT
}

\section{Training for Making Meat Fish for Hunter Group and Meat Sellers in Ukopti Village of The Arfak Mountain Natural Reserve Area Of West Papua}

\author{
Hotlan Manik*, Sangle Yohannes Randa, John Arnold Palulungan \\ Fakultas Peternakan, Universitas Papua Manokwari \\ Jalan Gunung Salju Amban, Manokwari Barat, Manokwari, Papua Barat
}

\author{
Article history \\ Received: Jul 1, 2020; \\ Accepted: Okt 20, 2020 \\ * Corresponding author: \\ E-mail: \\ h.manik@unipa.ac.id \\ DOI: https://doi.org/10.465 \\ 49/igkojei.v1i1.151
}

\section{ABSTRACT}

The Arfak Mountains Natural Reserve (CAPA), which is located in the Bird's Head Peninsula region of West Papua, Indonesia, covered about 45,000 $\mathrm{km} 2$. The area is located in the three different administrative areas, including Manokwari, Manokwari Selatan and Pegunungan Arfak regencies. Ukopti village located in the District Land Rubuh Manokwari District which is a buffer area (buffer zone) directly adjacent to the nature reserve area Mountains Arfak (CAPA). Economic circumstances village community is marginal and underprivileged, livelihood obtained from the garden uncertain so the other alternative is dependent on wildlife, especially deer hunting. Based on the decision of the Minister of Forestry and Plantation No: 682 / Kps-II / 1988 on the establishment of the Timor deer (Cervus timorensis) for game hunting in Papua, the Timor deer is a species of potential to improve the nutritional and economic society far will access conventional livestock. Community groups have only selling his catch in the form of fresh deer meat and bacon so often the quality of the prey easily damaged because it is not sold and the distance to the district town far enough and of sufficient transport side expensive.IbM activity lasted for eight months held at Kampung Ukopti Land District Rubuh Manokwari District. Two groups were used as partner or target group of these activities is to hunt and butcher deer group. Stages of these activities include lectures, demonstrations and hands-on participants. Results of the practice of making jerky deer had to be adopted by the community / partners who have received training, as shown by the products produced according to the example given participants. This activity is highly appreciated by the people of Kampung Ukopti, indicated by the presence of officers and most of the people during the activity.

Keywords: Reindeer jerky; Entrepreneur; The Arfak Mountains Natural Reserve Area

\section{ABSTRAK}

Cagar Alam Pegunungan Arfak (CAPA) yang terletak di wilayah Kepala Burung Papua Barat, Indonesia, luasnya sekitar $45.000 \mathrm{~km} 2$. Wilayah tersebut terletak di tiga wilayah administratif yang berbeda yaitu Kabupaten Manokwari, Manokwari Selatan dan Pegunungan Arfak. Kampung Ukopti terletak di Distrik Tanah Rubuh Kabupaten Manokwari yang merupakan daerah penyangga (buffer zone) yang berbatasan langsung dengan kawasan Cagar Alam Pegunungan Arfak (CAPA). Keadaan ekonomi masyarakat desa yang marjinal dan kurang mampu yang diperoleh dari kebun yang tidak menentu sehingga alternatif lainnya bergantung pada satwa liar, khususnya berburu rusa. Berdasarkan Keputusan Menteri Kehutanan dan Perkebunan Nomor: 682 / Kps-II / 1988 tentang Penetapan Rusa timor (Cervus timorensis) untuk pemburuan di Papua, Rusa 
timor merupakan salah satu spesies yang berpotensi untuk meningkatkan gizi dan gizi. Masyarakat ekonomi jauh akan mengakses ternak konvensional. Kelompok masyarakat yang selama ini hanya menjual hasil tangkapannya berupa daging rusa segar dan bacon seringkali kualitas mangsanya mudah rusak karena tidak laku dan jarak ke kota kabupaten cukup jauh serta sisi angkutan yang cukup mahal. Kegiatan ini berlangsung selama delapan bulan bertempat di Kampung Ukopti Tanah Distrik Rubuh Kabupaten Manokwari. Dua kelompok yang dijadikan mitra atau kelompok sasaran kegiatan tersebut adalah kelompok berburu dan menyembelih rusa. Tahapan dari kegiatan ini meliputi ceramah, demonstrasi dan peserta langsung mempraktekan pembuatan dendeng. Hasil praktek pembuatan dendeng harus diadopsi oleh masyarakat / mitra yang sudah mendapatkan pelatihan, terlihat dari produk yang dihasilkan sesuai contoh yang diberikan peserta. Kegiatan ini mendapat apresiasi yang tinggi dari masyarakat Kampung Ukopti yang ditunjukkan dengan kehadiran petugas dan sebagian besar masyarakat selama kegiatan berlangsung.

Kata kunci: Dendeng rusa; Pengusaha; Kawasan Cagar Alam Pegunungan Arfak

\section{PENDAHULUAN}

Kampung Ukopti terletak di wilayah Distik Tanah Rubuh Kabupaten Manokwari yang merupakan kawasan penyangga yang berbatasan dengan Kawasan Cagar Alam Pegunungan Arfak (CAPA) dengan luas $45.000 \mathrm{~km} 2$, terletak diwilayah Kepala Burung Propinsi Papua Barat, yaitu koordinat $01^{\circ} 00^{\prime}$, sampai $01^{\circ} 29^{\prime}$ LS dan $133^{\circ} 53^{\prime}$, sampai $134^{\circ} 15^{\prime}$ BT. Kawasan pelestarian alam termasuk dalam tiga wilayah kabupaten di Provinsi Papua Barat, yaitu Kabupaten Manokwari, Kabupaten Manokwari Selatan dan Kabupaten Pegunungan Arfak.

Kampung Ukopti didiami oleh dua suku asli yaitu Suku Hatam dan Moile, seperti umumnya suku asli di Papua selalu berpindah-pindah dalam hal membuat kebun (shifting cultivation). Pada ladang penduduk dikampung ini banyak diusahakan tanaman, seperti ubi jalar (Ipomea batatas), ubi kayu (Manihot utilissima), pepaya (Carica papaya), talas (Cholocasia sp), jagung (Zea mays), bawang (Allium sp.) dan kentang (Solanum sp.). Kampung Sigim dan Sinaitousi umumnya beternak babi (Sus sp.) dan Ayam Kampung (Gallus sp.) untuk kondisi sekarang mereka telah beternak sapi bali (Bos Sondaicus). Sistem beternak pada kampung ini masih sederhana seperti hanya melepaskan ternaknya keladang maupun hutan sekitar CAPA sehingga hasil yang diperoleh belum optimal.

Perburuan secara tradisional dilakukan dengan cara aktif maupun cara pasif. Perburuan satwa secara berkelompok apabila ada acara khusus, seperti: pelantikan kepala kampung, peresmian rumah ibadah (gereja), pendeta jemaat (gembala) serta kunjungan pejabat pemerintahan. CAPA juga merupakan habitat hewan Burung Cenderawasih (Paradisea sp.), Burung Namdur/Burung Pintar (Amblyornis inornatus), Landak Paruh Panjang (Zaglossus bruijnii), Maleo Gunung (Aepypodius arfakianus), Kangguru Pohon (Dendrolagus sp) yang merupakan hewan endemik yang status konservasinya terancam punah namun di beberapa kampung, hewan tersebut merupakan sasaran perburuan yang banyak dicari saat ini.

Rusa timor (Cervus timorensis) merupakan satwa potensial untuk kepentingan ekonomi masyarakat di Kampung ini. Perburuan aktif terhadap rusa merupakan pekerjaan utama sebagai masyarakat peramu di Kampung Ukopti dan biasanya dilakukan secara tradisional dengan mengunakan panah, parang dan tombak, sedangkan perburuan pasif dengan menggunakan jerat.

Pemasaran daging rusa dilakukan dengan menjual daging segar rusa hasil buruan di Kampung Ukopti atau kampung terdekat lainnya. Jika tidak laku dijual, hasil buruan hanya dikonsumsi sendiri atau diasar (diasapi) untuk memperpanjang waktu simpan. Pemburu menjual langsung ke konsumen atau berdasarkan pemesanan, terutama untuk acara-acara penting atau keagamaan. 
Bentuk pengawetan daging rusa yang dilakukan oleh masyarakat Kampung Ukopti merupakan bagian kearifan lokal masyarakat Suku Hatam dan Moile yang sudah diturunkan secara turun temurun sejak nenek moyang ada yaitu dengan pengasapan dan penjemuran.

\section{METODE}

Upaya pemecahan masalah tersebut menggunakan pendekatan sosiokultural partisipatif dengan metode transfer ilmu pengetahuan dan teknologi, seperti pelatihan dan pendampingan dalam pengolahan dan pengawetan daging rusa. Metode dan pendekatan yang ditawarkan untuk mengatasi permasalahan ekonomi dan kepentingan dalam pemanfaatan hasil hutan, tim telah membuat skala prioritas yang telah disepakati didalam program IbM ini adalah: (1) pelatihan pembuatan dendeng rusa dengan varian rasa manis dan asin ; (2) Penyuluhan tentang pentingnya melindungi dan pemanfaatan satwa liar di kawasan Cagar Alam; (3) Pelatihan manajemen keuangan sederhana dalam pemasaran usaha dendeng rusa; (4) membantu pembuatan pengemasan produk dendeng yang dibuat; (5) melatih mahasiswa belajar bekerjasama dengan kelompok mitra. Target program ini adalah adanya kemampuan masyarakat terutama kelompok mitra pemburu dan penjual daging rusa putus sekolah di Kampung Ukopti mampu mandiri membuat dendeng rusa sebagai salah satu usaha ekonomi sehingga. Luaran dari program IbM ini adalah: (1) kemampuan masyarakat sekitar kawasan penyangga membuat dendeng rusa dengan berbagai varian rasa; (2) kemampuan mitra dalam melakukan usaha dendeng rusa ; dan (3) produk dendeng

\section{HASIL DAN PEMBAHASAN}

Karya utama dari rangkaian kegiatan ini adalah produk dendeng rusa dengan varian rasa bagi mitra pemburu dan penjual daging rusa khususnya yang putus sekolah agar mereka nantinya dapat membagikan ilmu yang telah dipelajari bagi masyarakat sekitar CAPA dalam rangka meningkatkan jiwa wirausaha dalam membantu memenuhi kebutuhan hidup ekonomi dan menghindari interaksi masyarakat akan pemanfaatan hasil hutan yang sangat tinggi. Berbagai kegiatan ekonomi lainnya dan penguatan kelembagaan usaha yang baik diharapkan dapat merangsang kegiatan masyarakat khususnya kaum pemuda yang tidak memiliki lapangan pekerjaan atau putus sekolah dapat berwirausaha kegiatan yang produktif.

Pemilihan teknologi pembuatan dendeng disesuaikan dengan keadaan dan kemampuan masyarakat kampung yaitu teknologi yang murah, aman, mudah dan tepat guna. Pengembangan teknologi diutamakan pada penyempurnaan kemampuan masyarakat asli Papua, hal ini bertujuan memudahkan pemahaman bagi masyarakat dikampung yang jauh dari jalur komunikasi luar dan tingkat pendidikan yang relatif rendah. Prosedur kerja yang dilakukan adalah

1. Demonstrasi pembuatan dendeng rusa

2. Pendampingan pembuatan buku kas sederhana

3. Pendampingan pembuatan kemasan dendeng rusa yang dibuat

4. Penyuluhan tentang perlindungan dan pemanfaatan satwa liar yang lestari

\section{DENDENG RUSA}

Tim memberikan pemahaman tentang manfaat dan kegunaan pengolahan daging segar menjadi dendeng. Dalam penjelasan ini tidak saja disampaikan kegunaan produksi dari sisi nutrisi dan teknologi olahan daging, tetapi juga bagaimana hasil produksi tersebut mendatangkan nilai ekonomi yang dapat menjadi sumber penghasilan bagi keluarga dan masyarakat. Selanjutnya Tim mendemostrasikan bagaimana proses olah daging untuk membuatnya menjadi dendeng.

Ketrampilan yang didemontrasikan meliputi bagaimana menangani daging secara higenis, kemudian bagaimana cara mengiris atau menyayat tipis daging segar. Selama ini irisan daging yang dilakukan oleh masyarakat masih terlalu tebal, sehingga proses pengeringan tidak berlangsung baik, karena bagian tengah terkadang masih basah yang memicu cepatnya daging olahan menjadi rusak. Persoalan lain, alat pengiris daging yang dipakai belum sesuai tidak saja dari kebersihan alat 
maupun bentuk alat yang digunakan. Umumnya masyarakat dalam mengiris daging mereka menggunakan parang, yang mereka gunakan juga untuk berkebun ataupun untuk memotong kayu. Oleh karena itu dalam penjelasan ini, Tim memperkenalkan pisau yang tepat untuk mengiris daging agar dihasilkan sayatan daging yang tipis. Irisan daging yang tipis akan memudahkan penyerapan bumbu dan juga proses pengiringan daging yang berjalan sempurna.

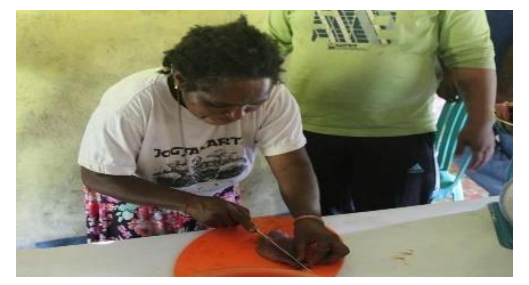

Gambar 1. Pembuatan dendeng rusa

\section{PENDAMPINGAN PEMBUATAN KEMASAN DENDENG}

Tim memberi penjelasan tentang perlunya penyimpanan lanjutan agar dendeng yang sudah dihasilkan tetap aman, yaitu dengan menyediakan kemasan. Peserta diperkenalkan dengan pengemasan plastik, cara penyiapan dan penutupannya. Kemasan plastik yang digunakan adalah plastik yang telah dipotong-potong untuk kemasan gula satu kilogram. Label kemasan disiapkan oleh Tim. Setiap satu kemasan diisi oleh dendeng seberat 250 gram. Setelah penimbangan, kemasan plastik ditutup dengan menggunakan panas lilin.

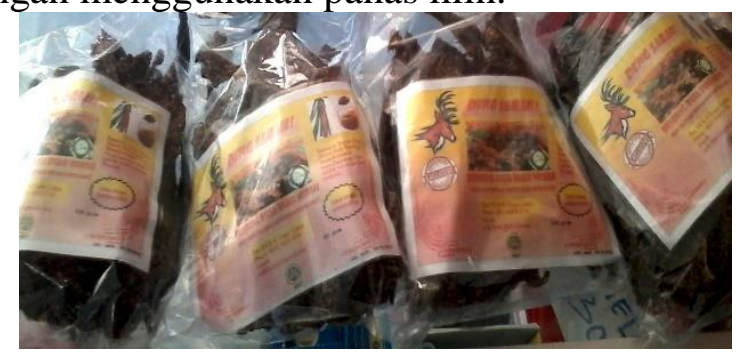

Gambar 2. Label kemasan yang diberikan bagi dendeng yang diproduksi

\section{PENYULUHAN DAN KEUANGAN USAHA DENDENG RUSA}

Guna melengkapi kemampuan peserta dalam usaha produksi dendeng sebagai sumber penghasilan atau ekonomi keluarga, peserta diberi ketrampilan penggunaan buku kas sederhana. Dalam pelatihan pembuatan buku kas, peserta dilatih menyusun arus anggaran yang terdiri dari pengeluaran dan penerimaan saja. Pengeluaran berisi hal-hal yang terkait dengan pembelanjaan modal, sedangkan penerimaan berisi catatan penjualan harian dari dendeng yang diproduksi.

Pada sesi ini, Tim juga melatih peserta untuk bagaimana dapat menghitung keuntungan usaha, yaitu dengan menghitung selisih antara biaya produksi dan penerimaan dari hasil penjualan. Biaya produksi terdiri daging segar, bumbu, peralatan, dan tenaga kerja. Analisis usaha dihitung per $1 \mathrm{~kg}$ daging segar sekaligus untuk menetapkan harga jual produksi. Meskipun daging rusa diperoleh dengan cara berburu, akan tetapi dalam perhitungannya harga daging tersebut disesuaikan dengan harga jual daging rusa segar di perkotaan, yakni seharga Rp50.000,- per kg. Harga bumbu Rp3.000,- ; peralatan Rp.5.000,-; tenaga kerja Rp2.000,-,dan transportasi Rp10.000. Sehingga total biaya produksi per kg adalah Rp70.000,-

Rataan rendemen dendeng rusa yang dihitung dari berat $1 \mathrm{~kg}$ segar adalah sebesar kurang lebih $50 \%$ atau 500 gram. Setiap kemasan berisi 250 gram, sehingga dari $1 \mathrm{~kg}$ daging segar rusa menghasilkan dua kemasan produksi. Untuk memperoleh keuntungan kasar, setiap kemasan dijual dengan harga minimal Rp50.000,-. $\quad$ Dengan kata lain, dari $1 \mathrm{~kg}$ daging segar untuk menghasilkan dendeng diperlukan biaya produksi sebesar Rp70.000.-. Jumlah kemasan yang diperoleh dengan diisi oleh dendeng seberat 250 gram diperoleh 2 kemasan, dengan harga total penerimaan Rp100.000,-. Sehingga keuntungan yang diterima dari pengolahan $1 \mathrm{~kg}$ daging rusa menjadi dendeng adalah sebesar Rp30.000,-. Bilamana dalam tiga bulan seorang anggota mitra dapat 
mengolah sekitar $20 \mathrm{~kg}$ daging segar, maka dalam setahun pendapatan bersih yang dapat dicapai oleh seorang mitra adalah sebesar Rp2.400.000,-

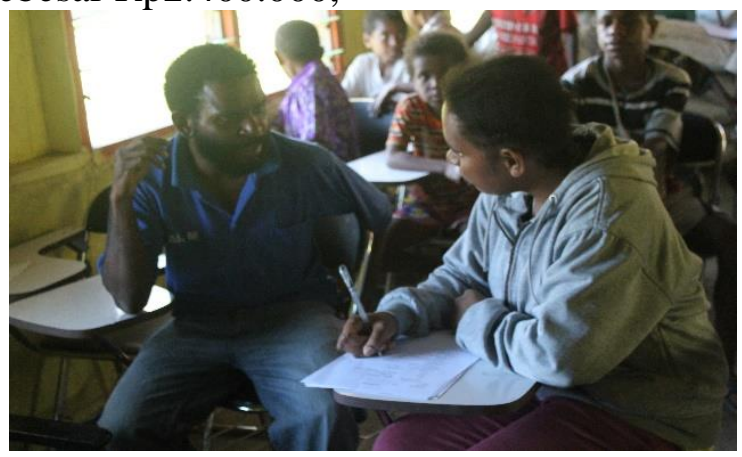

Gambar 3. Pendampingan pembuatan buku kas sederhana

\section{KESIMPULAN}

Berdasarkan hasil kegiatan IbM ini dapat disimpulkan bahwa : Materi penyuluhan dan demonstrasi pembuatan dendeng sangat dibutuhkan oleh masyarakat di Kampung Ukopti yang merupakan daerah penyangga dekat kawasan cagar alam pegunungan arfak. Adanya keinginan yang kuat untuk membuat dendeng rusa dibuktikan dengan antusiasnya peserta pelatihan mencoba membuat sendiri seperti mengiris daging dan mencampurkan bahan pembuatan dendeng. Kegiatan ini sangat diterima oleh masyarakat kampung khususnya masyarakat asli papua yang secara pendidikan maupun kemampuan bahasa terbatas terhadap akses tehnologi, hal ini dapat dilihat dari jumlah peserta yang hadir dan penerimaan tim kegiatan oleh kepala kampung maupun aparatnya.

Keberlanjutan program ini dapat dilakukan dengan skema kampung binaan oleh LPPM UNIPA ataupun dengan berbagai program pendampingan dari instansi pemerintah yang terkait maupun Lembaga Swadaya Masyarakat.

\section{UCAPAN TERIMAKASIH}

Ucapan terima kasih disampaikan kepada Direktorat Penelitian dan Pengabdian kepada Masyarakat Direktorat Jenderal Penguatan Riset dan Pengabdian Masyarakat yang telah membiayai melalui Program Ipteks bagi Masyarakat (IbM) tahun 2015. Selanjutnya kepada kelompok pemburu dan penjual daging rusa serta masyarakat Kampung Ukopti atas partisipasi dan kerjasamanya.

\section{DAFTAR PUSTAKA}

Indrawan M, Primack R dan Supriatna J. 2007. Biologi Konservasi. Yayasan Obor Indonesia.Jakarta Kartisari S, Marshall AJ. dan Beehler BM. 2012. Ekologi Papua. Yayasan Obor Indonesia dan Concervation Internasional. Jakarta

Manik H. 2008. Ekologi Persarangan Burung Maleo Gunung (Aepypodius arfakianus) pada areal Aliran Kali Mokwam Kabupaten Manokwari Papua Barat. Jurnal Ilmu Peternakan. Vol 3 (2) hal 101-106. 